\title{
STN1 Gene
}

National Cancer Institute

\section{Source}

National Cancer Institute. STN1 Gene. NCI Thesaurus. Code C131359.

This gene is involved in DNA replication and telomere maintenance. 